\title{
In search of an adequate novel on the democratic changes of 1989/1990. A paradigmatic approach
}

The historical events in Poland that followed the year 1989 should be regarded in a broader, Central European context. The history, culture and literature emerging after the so called "Autumn of the Nations" should be considered, and so should the literary reconstruction of Central Europe in literary texts. The revolutionary Polish movement of Solidarity (Solidarność) helped to restore Poland's and Central Europe's freedom in the tradition of "For our freedom and yours" (Za wolność naszą i waszą). In this way, Solidarity became an important part of a common, shared political and cultural heritage of Europe and the world. Many writers from East-Central Europe remember the noble slogan "for our freedom and yours". Irena Brežná, an author of Slovak descent, who writes in German, recognizes in Poland the "leading force in Central Europe in the struggle for freedom and independence", emphasizing that "Für unsere und eure Freiheit" is the appropriate bon mot for all revolutionary changes in Central Europe ${ }^{1}$. The Solidarity movement had also helped to introduce the idea of East-Central Europe as an integral part of the West ${ }^{2}$. Thus, Poland became a genuine exemplary model of the struggle for freedom and independence in the transformation process following 1989. May Poland again claim such a leading role in the crucial changes in Central Europe nowadays? According to French philosophers Jean-Marc Ferry and Paul Thibaud, we could state that the ethics of the Solidarity movement still remains an important part of further visions of a united Europe as a cultural and "socio-political proposal of universal validity"3. Unfortunately, the present developments in Poland demonstrate that the PiS-led administrations are more and more missing this opportunity by destroying the heritage of the Polish Solidarity movement as well as the paradigmatic democratic achievements after the year 1989.

The collapse of communism across Central and Eastern Europe, which began in Poland and Hungary, was symbolized by the fall of the Berlin wall in 1989, the reunification of Germany and Europe. Literary reactions to this historical caesura
HANS CHRISTIAN TREPTE

Universität Leipzig

1. I. Brezna, Wie ich auf die Welt kam. In der Sprache zu Hause, Zürich 2018, p. 29.

2. B. Chołuj, Die Renaissance des Begriffes Mitteleuropa. [in:] Europastudien. T. Beichelt, B. Chołuj et al. (eds.), Wiesbaden 2006, pp. 112-125, here p. 114.

3. J.-M. Ferry, P. Thibaud, Discussion sur l'Europe, Paris 1992. 
have to be treated as a long-lasting process of "evolving or revolving"4 all over East-Central Europe. What is the specific feature of this region, though? Essential characteristics could be seen in the particular geopolitical and cultural situation of East-Central Europe under totalitarian rule and its formative influence on culture and literature. Further studies should therefore concentrate on similar trends and different developments in Polish, Czech, Slovak, Hungarian and other literatures of the region.

As an important starting point, we might consider the statement that the East-Central European countries were kidnapped by the Soviet Union as a result of the Yalta Agreement after the end of World War II. It was the Czech writer Milan Kundera whose novel The Tragedy of Central Europe aroused long-lasting discussions on the tragic fate of Central Europe, "culturally western, politically in the East and geographically in the centre" ${ }^{\prime 5}$. It was the Polish writer Czesław Miłosz, in turn, who in The Captive Mind (Zniewolony umyst) ${ }^{6}$ described the moral conflicts of intellectuals in Eastern Europe and the ramifications that surrounded them. On the other hand, the Polish émigré writer Witold Gombrowicz tried to provide a definition of Poland in Europe, emphasizing the "in-between nature" of Central Europe in general: "It [Poland] is a country between the East and the West, where Europe starts to draw to an end, a border country where the East and the West soften into each other," placing Poland on the periphery somewhere between "Form (centre)" and "Chaos" (the outside world $)^{7}$. I would also like to mention the Hungarian writer György Konrád, who first demonstrated the process of indoctrination in his essay The Dream of Central Europe, and then - in Die Erweiterung der Mitte. Europa und Osteuropa am Ende des 20. Jahrhunderts focused on the enlargement of the centre - or of heart - of Europe after 1989/1990 ${ }^{8}$. All these publications had a significant influence on debates on the future of Europe. An immediate return to Europe, to the (democratic) West, was unanimously proclaimed after 1989/1990: "zpět do Evropy", "powrót do Europy", "visszatérés Európá$\mathrm{ba}^{\prime \prime}$. Artistic literary accomplishments related to the event took a much longer time to come to light.

In June 1989, a crucial round-table discussion was organized in Budapest on the fate of Central Europe. It gathered such writers as Péter Eszterházy, Danilo Kiš, György Konrád, Claudio Magris, Czesław Miłosz, Adam Michnik and many others. In his opening paper, Miłosz defined Central Europe as follows: "all the countries [including the Baltic States] that in August 1939 were the real or hypothetical object of a trade between the Soviet Union and Germany" ${ }^{\prime 10}$. We may regard Central Europe as a common, shared cultural heritage with different approaches of European intellectuals taking Central Europe also as an important lieux de memoir in their search of home and identity. The starting point of contemporary Central European reflections on identity is first of all the shared experience of communist dictatorship with different points of reference in the past. Therefore, a clear revival of the debate on Central Europe can be seen in various works of contemporary literature, mainly in those written by representatives of the younger generation. The

4. J. Rupnik, Evolving or Revolving? Europe since 1989, "EUROZINE", 15 December 2007.

5. M. Kundera, Un occident kidnappé ou la tragédie de l'Europe central, "Le Débat" 27 (1983).

6. C. Miłosz, The Captive Mind, London 1953.

7. W. Gombrowicz, A Kind of Testament, D. de Roux (ed.), trans. A. Hamilton, Philadelphia 1973, p. 53.

8. G. Konrád, Die Erweiterung der Mitte. Europa und Osteuropa am Ende des 20. Jahrhunderts, Wien 1999.

9. J. Rupnik, Evolving or Revolving? Europe since 1989.

10. Quoted by M. Cornis-Pope, J. Neubauer, Towards a History of the Literary Cultures in East-Central Europe: Theoretical Reflections, American Council of Learned Societies, ACLS OCCASIONAL PAPER, No. 52, 2002, p. 2. https://publications.acls.org/0P/ 0ccasional_Paper_052_2002.pdf (date of access: 18.11.2020). 
novel, as a literary form from the domain of belles lettres, does not react to current events as quickly as more "operative" literary forms such as journalism, travelogues or essays. Since literary reflection does not automatically accompany political changes, it takes much more time for a comprehensive novel on the democratic turning point of 1989/1990 to appear on the European book market. Nevertheless, the turning point of 1989/1990, in which, to quote Małgorzata Czermińska, a prominent Polish literary scholar, "Central Europe broke free from communism was not only a reversal of the political development" but also a "deep cultural shock which affected every sphere of life" ${ }^{\prime 11}$. Czerminska's statement applies not only to Polish prose writing. It is of prime importance for other literatures in Central Europe, manifesting itself in two main literary tendencies. One is the concentration on "personal autobiographical experience" in combination with "documentaries"; the other is concentrating first of all on "literary imagination" - that is, on literary fiction par excellence ${ }^{12}$.

Expectations of the readers as well as of literary critics run high, demanding impatiently a universal, comprehensive "Wenderoman", a seminal novel on the peaceful revolution in post-communist East-Central Europe as well as in Germany. As a matter of fact, though, there is little agreement about an adequate term for the German word "Wende".
The pragmatic head of the Protestant Nicolaikirche in Leipzig, Christian Führer, named the changes taking place in Leipzig and East Germany a "peaceful revolution" of a "biblical dimension"13. That is why I will also use the more adequate term "peaceful revolution" than "Wende" which was used by the East German leader Egon Krenz characterizing a "change" within the Socialist Unity Party (SED) aiming at a political and ideological offensive ${ }^{14}$.

A question could be raised, nevertheless, if Central European literatures after 1989/1990 could be "free from ideological and political goals" and, as such, also "more universal"15. Expectations that writers in an independent Poland after 1989/1990 would feel liberated from traditional political roles - and that they would end their preoccupation with national affairs - proved to be wrong ${ }^{16}$. What, instead, could be the characteristic attributes of literary works emerging after 1989/1990? “Post-dependent novels describe spaces where language, culture and traditions converge along colliding paths toward national, collective and artistic self-realization [...] exploring the 'in-between spaces' where collective and individual identities are formed, the site and symbol of transition, of transfer and transformation. [...] And yet, the changes of 1989 hardly warranted an emphasis on the intellectualization of entertainment as the population eagerly embraced status symbols of the West"17.

11. M. Czermińska, On The Turning Point: Polish Prose, 1989-1995, “Canadian Slavonic Papers/Revue canadienne des slavistes" Vol. XXXIX, 1-2, March-June 1997, pp. 109-122, here p. 107.

12. Ibid.

13. C. Führer, Und wir sind dabei gewesen: die Revolution, die aus der Kirche kam, Berlin 2009. The peaceful revolution in the GDR can be compared with revolutions in Central Europe, beginning with the bloody uprising in Poland, the bloody revolution in Romania, the velvet revolution in Czechoslovakia up to the revolution of all decent people in Slovakia.

14. "Mit der heutigen Tagung (Sondersitzung des SED-Zentralkomitees HCT) werden wir eine Wende einleiten." B. Carstensen, Wörter des Jahres 1989, "Sprache und Literatur in Wissenschaft und Unterricht” 20 (64) 1989, p. 111.

15. M. Gliński, Not Waiting For a Masterpiece (Anymore). Polish literature After 1989, “CULTURE.PL language \& literature”, 6 August 2013. https://culture.pl/en/article/not-waiting-for-a-masterpiece-polish-literature-after-1989 (date of access: 18.11.2020). https://culture.pl/en/article/not-waiting-for-a-masterpiece-polish-literature-after-1989 (date of access: 18.11.2020).

16. T. Walas, Zrozumieć swój czas: kultura polska po komunizmie: rekonesans, Kraków 2003.

17. J.D. Caytas, The Polish Novel After 1989: Common Elements in Polish Post-Dependent Literature. https://www.researchgate.net/ publication/256061580_The_Polish_Novel_After_1989_Common_Elements_in_Polish_Post-Dependent_Literature (date of access: 18.11.2020). https://books.google.de/books?id=z6j3CwAAQBAJ\&pg=PA85\&hl=de\&source=gbs_toc_r\&cad=2\#v=onepage\&q\&f=false (date of access: 18.11.2020). 
A paradigmatic example of rewriting Central Europe could be Andrzej Stasiuk's and Yurii Andrukhovych's double essay My Europe: Two Essays on So-called Central Europe (Moja Europa. Dwa eseje o Europie zwanej Srodkowa $)^{18}$. It is a new, instructive approach to a region situated between Poland and the Ukraine beyond previous narratives. There are significant differences between cultures and literatures all over Central Europe that result from different local conceptions of democracy, state, nation, national culture, literature, and heritage. Therefore, interdisciplinary approaches and cross-border research are of great help for anyone who wants to rethink the process of democratic changes and backsliding as typical regional trends in East-Central Europe. The integration of East-Central Europe into a new democratic system has set a significant challenge for the West and the East. Many countries in East-Central Europe lack the advantage of strong democratic experience, traditions and elites other than those of dissidents and emigrants. Growing ethnic nationalisms, populism, heterogeneous social movements, immigration, increasing public apathy and disillusionment, in turn, present a threat to long-term stability and continuity in East-Central Europe, provoking many commentators to ask a major question: "What has Eastern Europe taught us about the democratization literature (and vice versa)?"19. The post-1989 imperative to imitate the West has also generated discontent, disappointment, and frustration. That is perhaps the primary reason why we can observe a decline of the liberal consensus in East-Central
Europe. The former success stories of democratic changes and of the integration with the West have changed considerably. There is a growing danger that East-Central Europe may move towards less democratic structures, that populist, nationalist and anti-European tendencies will increase further, signalizing an "illiberal turn"20, and leading to a "conservative backlash" 21 , which will cause new divisions between "global civil societies" in the West and new nationalisms in the East ${ }^{22}$. How does literature respond to all of that? How can it do so in the future? Is it necessary to explain the often-misunderstood East to the West again, to "tell the West" more about the "other Europe"?

It was the American writer Philip Roth, who edited "Writers from the Other Europe" series for the readers in the West ${ }^{23}$. Traditional and new imaginations of East-Central Europe seem to return in many books today. Young writers of East European descent refer to apparently forgotten ideas of this region. In this context, it is worth considering the statement of the Czech author Eduard Goldstücker, a scholar of Franz Kafka, made in November 1990, that a precious novel would come first of all from East-Central Europe, where writers mostly have to cope with a complicated past. To be "Eastern European" seems to be even "punk" today. A question arises, then: what remains of the "veterans of the past" (of the "time of fear and hate"24 that the Czech author Jáchy Topol referred to when he said: "I was raised on the myth of a new Central Europe, advocated by such distinguished authors as Hrabal, Havel, Miłosz, Konrád, Kundera", but it "is only

18. J. Andruchowycz, A. Stasiuk, Moja Europa. Dwa eseje o Europie zwanej Środkowa, Wołowiec 2001.

19. P. Kopecký, What has Eastern Europe taught us about the Democratization literature (and vice versa)? "European Journal of Political Research", 26 of September 2003. Compare also: The European Commission: 25 years after the fall of the Iron Curtain. The State of Integration of East and West in the European Union, Luxembourg 2014.

20. The Illiberal Turn. https://www.illiberal-turn.eu/ (date of access: 18.11.2020).

21. Conservative Backlash in Europe. https://discretion.uib.no/events/conservative-backlash-in-europe/ (date of access: 18.11.2020).

22. Ibid.

23. P. Roth, Writers From the Other Europe (4 volume set), Penguin Paperback Series, New York City 1976-1989. Danilo Kiš, Milan Kundera, Ludvik Vaculik, Bohumil Hrabal, Bruno Schulz, Jerzy Andrzejewski, Tadeusz Borowski, György Konrád.

24. J. Topol, It's Punk to be Eastern European: Jáchym Topol on his Homeland. https://www.musicandliterature.org/features/2019/2/16/ its-punk-to-be-eastern-european (date of access: 18.11.2020). 
when I get out of Prague that I encounter the label 'Eastern European' or 'Western European' writer")?25 Many literary newcomers continue Central-European traditions by modifying crucial topics of the communist time in a creative way. Among Czech writers, it is important to mention Jáchym Topol, Radka Denemarková, and Jaroslav Rudiš. Topol's masterpiece of post-communist fiction, Sestra (in the English translation: City Sister Silver $)^{26}$, describes the volcanic eruptions and the emotional dislocation following the velvet revolution of 1989 including dreams, romance, horror, intrigue as well as satire. In the West, most of these narratives were recognized first of all as documentaries. As a result of the "spatial turn"27, new landscapes of Central Europe are discovered again, not only in national but also transnational contexts. With the help of a new, often provoking language, theses authors do not see a special national mission in their narratives anymore, they rather prefer writing against a chaotic and unacceptable "strange new world"28.

A prominent part of the literary debate on Central Europe and the democratic turning point of 1989/1990 is the insightful process of re-thinking, re-writing and re-reading ${ }^{29}$ of the disappeared German Democratic Republic (GDR) and its literature. "Narratives of East/West dichotomy were fairly black and white (with heroes and villains switched out depending on which side of the Iron Curtain you lived in) [...] Such ambiguity also manages to come through in the heavily-censored literature of the GDR, and it is more openly explored in books written post-1989 by German and non-German authors alike" ${ }^{\prime \prime}$. It seems to be crucial that the outside view enables writers much more to compare precisely what has happened after the turning point of 1989, what was following afterwards and what remains today in a "second coming in academic seminars, conferences, books, and journals. [...] Literature has often been the only medium of public communication about life in East Germany $^{\prime 31}$. That is why Christa Wolf, one of the most important German-German writers, spanned Germany's East-West divided in her literary work. Her book City of Angels or The Overcoat of Dr. Freud $(2013)^{32}$ deals with life after the German reunification. East Germany and the fall of the Berlin Wall continue to be a vivid literary theme in German literature today.

I would like to concentrate now on literary works of authors in a closer Polish-German context. One of the Polish eyewitnesses of the political changes in East Germany was Henryk Sekulski. In his novel Przebitka (2001) ${ }^{33}$, the author analyses

25. Ibid.

26. J. Topol, City Sister Silver, North Haven 2000.

27. D. Bachmann-Medick, Cultural Turns. Neuorientierungen in den Kulturwissenschaften, Reinbek bei Hamburg 2014.

28. https://www.dw.com/en/leipzig-book-fair-spotlight-on-4-contemporary-czech-novels/a-47935507 (date of access: 18.11.2020).

29. https://www.mod-langs.ox.ac.uk/gdrculture/Programme.pdf (18.11.2020).

30. 0. Giovetti, Reading Beyond the Wall: 7 Acclaimed Books About And from East Germany. On the 30th Anniversary of the Fall of the Berlin Wall, "Literary Hub. The Best oft he Literary Internet", November 8, 2019. https://lithub.com/reading-beyond-the-wall7-acclaimed-books-about-and-from-east-germany/ (date of access: 18.11.2020). Compare also: M. Latkowska, The Political Role of East and West-German Writers Before and After 1989, August 2010. https://www.researchgate.net/publication/233002376_ The_Political_Role_of_East-_and_West-German_Writers_Before_and_After_1989 (date of access: 18.11.2020).

31. M. Silberman, What remains? East German Culture And the Postwar Public. Forword. Harry\&Helen Gray Humanities Program Series. Volume 2. University of Wisconsin. https://www.aicgs.org/site/wp-content/uploads/2011/11/silberman.pdf (date of access: 18.11.2020) and L.A. Adelson, The Cultural After-Life of East Germany: New Transnational Perspectives, Washington DC: 2002. Narrating the Fault Lines: East German Literature since the Fall of the Wall, "World Literature Today", November 2014. https://www.worldliteraturetoday.org/2014/november/narrating-fault-lines-german-literature-fall-wall-necia-chronister (date of access: 18.11.2020).

32. C. Wolf: Stadt der Engel oder The Overcoat of Dr. Freud, Berlin: 2010; City of Angels or The Overcoat of Dr. Freud, New York 2013.

33. H. Sekulski, Przebitka, Olsztyn 2001. 
the GDR reality and East German citizens mainly in Leipzig in comparison with political events and social developments in Poland. A similar approach also from a rather Polish perspective might be observed in other literary works of writers of Polish descent like in Brygida Helbig's Ossis und andere Leute $^{34}$ (2015), Kazimierz Brakoniecki's diary Dziennik berliński (2011), Andrzej Kasperek's melancholic narrative Back in the GDR (2010), Krzysztof Wojciechowski's Moi kochani Niemcy (2002) or Magdalena Parys's crime novels Tunnel (2011, Der Tunnel 2014) and Magic - Magik (2014). Revealing is Brygida Helbig's statement that after the reunification of Germany the former residents of the GDR became foreigners in their own country, and that the united German state did not turn into a new home for them. A similar distancing attitude towards the German (re)unification is expressed in Sekulski's Przebitka: "I observed the whole thing with distance: it's a shame to admit, but I was a bit sorry for it, for the GDR, I got used to it, I knew it from the ground up and that's why I said goodbye wistfully" ${ }^{\prime \prime}$.

Emilia Smechowski, a writer of Polish decent, offers an interesting approach and a promising idea in her book Rückkehr nach Polen. Expeditionen in mein Heimatland (Return to Poland. Expeditions into my home country) ${ }^{36}$. The author writes about her personal experience of the cognitive process of being "in-between" - lost and found at the same time. The title of the book is characteristic of a general tendency in contemporary Central European literatures that concentrate on the search for lost family traces, lost places, and memories. The literary intention of Smechowski to characterize Poland's development after 1989 seen through Polish-German eyes is laudable, indeed, but the form it takes seems imperfect. Peter Oliver Loew finds Smechowski's text to be forced and plagued by mistakes, half-truths, faulty inquiries and over-simplifications ${ }^{37}$.

Does the fog which engulfed Central Europe during the cold war, and which had lifted after 1989, come back again? ${ }^{38}$ As a matter of fact, Central Europe is back on the literary scene, closely linked with the prominent question: "Is there such a thing as Central (Eastern) European literature? May we reconsider a Central European consciousness on the basis of contemporary literature?"39. Is there a "renaissance of Central Europe" 40 , "Central Europe redivivus"? 41 . The children and grandchildren of the transformation of 1989/1990 entered the literary scene, carrying less historical luggage. They seemed to get rid of their parents' and grandparents' burden. But in the end, however, it seems that even for them there is no true escape from Central European history. The pendulum of history seems to swing back again. History, once driven out of the door, has come back through the windows again.

34. B. Helbig, Enerdowce $i$ inne ludzie, Szczecin 2011; Ossis und andere Leute, Greifswald 2015.

35. Ibid., p. 305. Translation into English: H.C.T.

36. E. Smechowski, Rückkehr nach Polen. Expeditionen in mein Heimatland, Berlin 2019.

37. P.0. Loew, Emilie Smechowski "Rückkehr nach Polen“. Von Fehlern, Halbwahrheiten und schlechter Recherche, "Cicero Magazin für politische Kultur“, 10. September 2019. https://www.cicero.de/kultur/emilie-smechowski-polen-deutschland-buch-recherche (date of access: 18.11.2020).

38. K. Raabe, As the fog lifted. Literature in eastern central Europe since 1989. "eurozine". https://www.zeitschrift-osteuropa.de/ site/assets/files/4047/2009-10-08-raabe-en.pdf (date of access: 18.11.2020).

39. M. Numano, Is There Such a Thing as Central (Eastern) European Literature? An Attempt to Reconsider 'Central European' Consciousness on the Basis of Contemporary Literature. Chapter 7. http://src-home.slav.hokudai.ac.jp/coe21/publish/no15_ ses/07_numano.pdf (date of access: 18.11.2020).

40. B. Chołuj, Die Renaissance des Begriffes Mitteleuropa.

41. S. Hänschen, Mitteleuropa redivivus? Stasiuk, Andruchovyč und der Geist der Zeit, "Osteuropa“, Vol. 54, No. 1 (January 2004), pp. 43-56. 
Is East-Central Europe backsliding today towards illiberal, more and more authoritarian and anti-European structures? In a letter put forward by the Polish Stefan Batory Foundation, intellectuals of the Visegrád states pleaded for an open and democratic society, distancing themselves from their own xenophobic and nationalistic political caste in favour of a real European solidarity ${ }^{42}$. It is a fundamental human experience - accumulated during the democratic revolutions - to defend democratic rights and individual freedom. Thus, we may observe a new "revolution of all decent people" - like the one in Slovakia. Irena Brežná puts it this way: "the word slušnost' (decency) turns into the similar sounding Slovak word poslušnost' (obedience) ${ }^{43}$, stating that "your end has come" - "odzvonilo vám"44 in a fight for democracy and a united Europe. This new revolution, based on the Czechoslovakian reform movement of 1968, the Solidarity movement in Poland and the velvet revolution of 1989, is believed to have changed "great national feelings into water vapor" in connection with the hope that "decent people" will not take a bath in "national anthems" again ${ }^{45}$. The vision of the Slovak writer Michal Hvorecký is quite bitter, in turn, in his controversial novel Troll ${ }^{46}$ (2018), originally thought as a piece of science fiction. Internet trolls, fake news, a dictatorship of evil, and intellectually limited dwarves are ruling in East-Central Europe, and "literature" is made now by "story-trolling agencies". Western Europe has changed into an isolated, "guarded fortress", whereas in the East there is the dictatorship of the "Empire of Evil" 47 . This is a grim vision indeed.

Does a phantom named "Central Europe" exist in literature today? ${ }^{48}$ This question was already answered by the Nobel Prize winner Olga Tokarczuk, who, while being in Japan, expressed herself as a "writer from Central Europe and not from Eastern Europe" 49 . She referred to Central Europe as a "belt of unknown belonging", an "intersection of Western and Eastern influences", which, like an illusion, "cannot be grasped simply by its essence" ${ }^{\prime 50}$. The Polish writer claimed that "Central European literature somewhat resembles a mushroom", an organism that began to grow "on top of the things that were slowly dying", that is "the solid and predictable world that met its demise at the outbreak of the First World War"51. Literature is meant to be provocative and writers should intervene to open people's minds, to make people think, to present new perspectives, looking for specific answers concerning the destruction of our planet, discrimination of minorities and all kind of inequalities.

The beginning of a new era after the turning point of 1989/1990 is an important "source of experience reflected", including the role of "civil societies, Charta 777, the civil rights movement and the citizens' movement of 'Solidarity' (Solidarność) [...]", Basil Kerski, journalist, essayist, political scientist and head of the European Solidarity

42. I. Brezna, Wie ich auf die Welt kam. In der Sprache zu Hause, p. 177.

43. Ibid., p. 189.

44. Ibid.

45. Ibid., p. 167.

46. M. Hvorecký, Troll, Berlin 2018.

47. "Trolle in 0steuropa sind stolz darauf, Trolle zu sein. Sie sind sogar stolz darauf, von Moskau finanziert zu werden. [...] Früher hätte man solche Leute Landesverräter genannt" (Im Visier der Trolle, "LVZ" Nr. 110, Montag, 13. Mai 2019, p. 3).

48. Fantom Europy przegląda się w literaturze. Czy istnieje powieść środkowo-europejska? A lecture delivered March 1, 2013 at Rikkyo University Tokyo on the image of the East in Eastern European Literatures.

49. H. Ogura, On New Travel Literature And Central Europe As a Blank Space: Notes On Olga Tokarczuk's Novel 'Bieguni' And Her Lecture Series in Japan. http://src-h.slav.hokudai.ac.jp/coe21/publish/no30_ses/p9-15.pdf (date of access: 18.11.2020).

50. Ibid.

51. Ibid. 
Centre in Gdańsk stated in his Leipzig speech on democracy on the occasion of the peaceful revolution in East Germany ${ }^{52}$. The critical analysis of the past of Central Europe will prepare the ground for new literary visions of Europe in disputes on the shared heritage and traditions of the peaceful revolution misused by populist, nationalist and liberal thinkers. Their false slogans proclaim that the democratic revolution has to be completed now: "Vollende die Wende!". The democratic turning point of 1989/1990 in Germany and Central Europe can be considered as an important base for further constructions and deconstructions in contemporary literature considering the political upheavals also as an end of a certain myth ${ }^{53}$. The quick adaptation to the West, the "takeover" of the East by the West gave way to different views: supposed disregard, ignorance and arrogance of the West towards different experience and moral attitudes in a generalized, unified East. The East-
-West debate in cultural, mental, social and political terms will go on, recognizing the achievements of the East with the aim to propagate democratic ideas of a "diverse Europe with different faces"54.

At the end, I would like to quote Michal Hvorecký again, who published an open letter with the programmatic title "I miss Central Europe" (Ich vermisse Mitteleuropa) addressed to his writer colleagues Tereza Semotamová (Czech Republic), Márton Gegely (Hungary) and Monika Sieradzka (Poland). In the letter, he wrote: "I miss the ideal of Central Europe that intended to mediate and to link. I love it and I don't want to be ashamed of my country today. The new division of the European Union along national egoisms and right-wing populist idiocy does hurt and worry me deeply. [...] East- Central Europe is still needed; it has a chance now, which we have to use instead of sacrificing it on the altar of right-wing populism and resignation" 55 .

52. https://www.leipzig.de/buergerservice-und-verwaltung/unsere-stadt/herbst-89/rede-zur-demokratie/ (date of access: 18.11.2020). B. Kerski, "Der kürzeste Weg in die Zukunft führt über die Vertiefung der Vergangenheit." Reflexionen über den Epochenwechsel 1989/1990 und seine Folgen. https://www.l-iz.de/wp-content/uploads/2020/10/Kerski.pdf (date of access: 18.11.2020).

53. H. Casper-Hehne, I. Schweiger (eds.), Deutschland und die "Wende" in Literatur, Sprache und Medien. Interkulturelle und kulturkontrastive Perspektiven, Göttingen 2008.

54. I.S. Kowalczuk, Die Übernahme. Wie Ostdeutschland Teil der Bundesrepublik wurde, München 2019.

55. „Ich vermisse das Ideal eines Mitteleuropas, das vermittelnd und verbinden wollte. Ich liebe es, und ich will mich heute nicht für mein Land schämen müssen. Die neue Teilung der EU entlang nationalstaatlicher Egoismen und rechtspopulistischer Idiotie verletzt und beunruhigt mich zutiefst. [...] 0stmitteleuropa wird noch gebraucht, es hat jetzt eine Chance, die wir nutzen müssen, anstatt sie auf dem Altar von Rechtspopulismus und Resignation zu opfern." M. Hvorecký, Ich vermisse Mitteleuropa. “ostpol“ 05.09.2018. https://ostpol.de/beitrag/5224-slowakei-ich-vermisse-mitteleuropa (date of access: 18.11.2020). 


\section{Bibliography}

Adelson, L.A., The Cultural After-Life of East Germany: New Transnational Perspectives, Washington DC 2002.

Bachmann-Medick, D., Cultural Turns. Neuorientierungen in den Kulturwissenschaften, Reinbek bei Hamburg 2014.

Casper-Hehne, H., Schweiger, I. (eds.), Deutschland und die "Wende" in Literatur, Sprache und Medien. Interkulturelle und kulturkontrastive Perspektiven, Göttingen 2008.

Caytas, J.D., The Polish Novel After 1989: Common Elements in Polish Post-Dependent Literature. https://www.researchgate. net/publication/256061580_The_Polish_Novel_After_1989_Common_Elements_in_Polish_Post-Dependent_Literature (date of access: 18.11.2020).

Chołuj, B., Die Renaissance des Begriffes Mitteleuropa. [in:] Europastudien. T. Beichelt, B. Chołuj et al. (eds.), Wiesbaden 2006, pp. 111-124.

Cornis-Pope, M., Neubauer, J., Towards a History of the Literary Cultures in East-Central Europe: Theoretical Reflections, American Council of Learned Societies, ACLS OCASSIONAL PAPER, No. 52, 2002, p. 2. https://publications.acls.org/0P/0ccasional_Paper_052_2002.pdf (date of access: 18.11.2020)

Czermińska, M., On the Turning Point: Polish Prose, 1989-1995, "Canadian Slavonic Papers/Revue canadienne des slavistes", Vol. XXXIX, 1-2, March-June 1997, pp. 109-122.

Ferry, J.-M., Thibaud, P., Discussion sur l'Europe, Paris 1992. Gliński, M., Not Waiting for a Masterpiece (Anymore). Polish Literature after 1989, “CULTURE.PL language \& literature”, August 6 2013. https://culture.pl/en/article/not-waiting-for-a-masterpiece-polish-literature-after-1989 (date of access: 18.11.2020). Giovetti, 0., Reading Beyond the Wall: 7 Acclaimed Books about and from East Germany. On the $30^{\text {th }}$ Anniversary of the Fall of the Berlin Wall, "Literary Hub. The Best oft he Literary Internet", November 8, 2019. https://lithub.com/reading-beyond-thewall-7-acclaimed-books-about-and-from-east-germany/ (date of access: 18.11.2020).

Hänschen, S., Mitteleuropa redivivus? Stasiuk, Andruchovyč und der Geist der Zeit, "Osteuropa”, Vol. 54, No. 1 (January 2004), pp. 43-56.

Kerski, B. "Der kürzeste Weg in die Zukunft führt über die Vertiefung der Vergangenheit" Reflexionen über den Epochenwechsel 1989/1990 und seine Folgen. https://www.l-iz.de/wp-content/uploads/2020/10/Kerski.pdf (date of access: 18.11.2020).
Kowalczuk, I.S., Die Übernahme. Wie Ostdeutschland Teil der Bundesrepublik wurde, München 2019.

Loew, P.0., Emilie Smechowski "Rückkehr nach Polen". Von Fehlern, Halbwahrheiten und schlechter Recherche, "CiceroMagazin für politische Kultur", 10 September 2019. https://www. cicero.de/kultur/emilie-smechowski-polen-deutschland-buchrecherche (date of access: 18.11.2020).

Numano, M., Is There Such a Thing as Central (Eastern) European Literature? An Attempt to Reconsider 'Central European' Consciousness on the Basis of Contemporary Literature. Chapter 7. http://src-home.slav.hokudai.ac.jp/coe21/publish/no15_ ses/07_numano.pdf (date of access: 18.11.2020).

Raabe, K., As the fog lifted. Literature in eastern central Europe since 1989. "eurozine". https://www.zeitschrift-osteuropa.de/ site/assets/files/4047/2009-10-08-raabe-en.pdf (date of access: 18.11.2020).

Rupnik, J., Evolving or Revolving? Europe since 1989, “EUR0ZINE", 15 December 2007.

Walas, T., Zrozumieć swój czas. Kultura polska po komunizmie: rekonesans, Kraków 2003.

\section{Abstract}

Literary debates on Central Europe often concern the problems of the democratic breakthrough in the former Eastern bloc. Central Europe is also a common cultural and literary heritage; however, it must be shown how literary visions resonated in specific discussions and literary works in various countries before and after the democratic transformation of 1989/1990. Revolutionary events in Poland resulted in the "Autumn of Nations", and the expectations of readers and critics for a suitable novel about the breakthrough and transformation process were high.

Keywords: (East-)Central Europe, communism, democratic turning point, revolution and democratic transition, shared heritage

Hans-Christian Trepte - Assistant professor, doctor emeritus in Institut für Slawistik, at Universität Leipzig; expert in Slavonic, English and literary studies; translator; his main research interests revolve around West Slavic literature and culture, (e)migration (from Central and Eastern Europe), language change and literary translation; in 1979, he obtained his doctorate in Leipzig awarded on the basis of the dissertation Zur Epochengestaltung in Jaroslaw Iwaszkiewiczs Roman "Sława i chwała"/ 
"Ruhm und Ehre". In 1989 in Leipzig he received the Facultas docendi in West Slavic cultures and literatures. Co-author: Zwischen Oder und Peipussee. Zur Geschichtlichkeit literarischer Texte im 20. Jahrhundert. Lüneburg 2001. Grundbegriffe und Autoren ostmitteleuropäischer Exilliteraturen 1945-1989. Ein Beitrag zur Systematisierung und Typologisierung. Stuttgart 2004. Identität Niederschlesien - Dolny Śląsk. Hildesheim 2007. Nationaltexturen. National-Dichtung als literarisches Konzept in Nordosteuropa. Hildesheim 2007; Alteritäten: Literatur, Kultur, Sprache. Hildesheim 2013. Zwischen Ost und West. Joseph Conrad im europäischen Gespräch. Leipzig 2010; Flüsse. Kultur und Literatur der Wasserwege Leipzig 2015. Zwischen Zentrum und Peripherie. Zu neuen und alten Fragen der (E) Migrationsliteratur. Leipzig 2016. Awards: Knight's Cross of the Order of Merit of the Republic of Poland (2001); Medal of Gratitude of the European Solidarity Center (2014). 